\title{
Underestimation of acute pancreatitis: patients with only a small increase in amylase/lipase levels can also have or develop severe acute pancreatitis
}

\author{
P G Lankisch, S Burchard-Reckert, D Lehnick
}

\begin{abstract}
Background-In most treatment studies on acute pancreatitis, pancreatologists base their diagnosis on amylase/lipase levels more than three times above the upper limit of normal $(>3 n)$ and thus exclude patients with smaller enzyme level increases. The recommendations derived from the results of treatment studies do not take into account such patients. Nonpancreatologists frequently believe that only patients with high enzyme levels have a serious prognosis.

Aims-To question the assumption that high enzyme levels indicate severe, and conversely low enzyme levels indicate mild, acute pancreatitis.

Patients/Methods-This retrospective study includes 284 consecutive patients with a first attack of acute pancreatitis. The cause was biliary in $114(40 \%)$ patients, alcoholism in $83(29 \%)$, other in $21(7 \%)$, and unknown in $66(23 \%)$. Patients were divided into two groups according to their serum enzyme levels (amylase: $\leqslant 3 n, n=88 ;>3 n, n=196$; lipase: $\leqslant 3 n, \quad n=51 ;>3 n, \quad n=233)$. Renal impairment, indication for dialysis and artificial ventilation, development of pseudocysts, necessity for surgery, and mortality were taken as parameters of severity.
\end{abstract}

Results-The incidence of severity was the same for both the $\leqslant 3 n$ and $>3 n$ groups.

Conclusions-The severity of acute pancreatitis is independent of the elevation in serum amylase/lipase level $(\leqslant 3 n$ or $>3 n)$ on admission. Patients with only a slight increase can also have or develop severe acute pancreatitis. Patients with $\leqslant 3 n$ elevated enzyme levels on admission represent a substantial group that treatment studies have frequently overlooked. This is especially true for patients with alcohol induced acute pancreatitis whose amylase levels are lower than in other aetiological groups.

(Gut 1999;44:542-544)

Keywords: acute pancreatitis; amylase; lipase; severity; prognosis; mortality

Physicians consider high levels of creatine kinase, serum creatinine, or C-reactive protein to be indicative of severe myocardial infarction, renal insufficiency, and inflammatory diseases. Non-pancreatologists often believe that the more elevated the level of the pancreatic enzymes the more severe the disease.

In most treatment studies on acute pancreatitis, pancreatologists based their diagnosis of the disease on amylase/lipase levels three times higher than the upper limit of normal $(>3 n) .{ }^{1-10}$ Recommendations derived from the results of these studies do not take into account patients with smaller enzyme increases - that is, three times or less than the upper limit of normal $(\leqslant 3 n)$ on admission.

The assumption that greatly elevated serum enzyme levels on admission are indicators of severe disease is questioned in our retrospective study.

\section{Patients and methods}

The study included 284 consecutive patients, both medical and surgical, admitted from 15 November 1986 to 30 April 1996 to our hospital with a first attack of acute pancreatitis. The diagnosis was based on characteristic signs and symptoms as well as on increased $\alpha$-amylase (enzymic colorimetric test) and/or lipase (UV test) (both tests from Boehringer-Mannheim, Mannheim, Germany) in serum and characteristic sonographic and/or computed tomographic (CT) findings. In 39 patients, amylase was normal on admission. Diagnosis was based on elevated serum lipase levels in all cases and on abnormal CT $(n=29)$ or ultrasound $(n=$ 18) scans. Patients with prior acute pancreatitis or episodes of unexplained abdominal pain were excluded from the study, as were patients in whom imaging disclosed signs of chronic pancreatitis. ${ }^{11}$

Alcohol induced acute pancreatitis was assumed when the patient or her/his relatives reported a regular daily alcohol consumption of more than 3 litres of beer or more than 120 g pure alcohol in the form of wine or schnapps or an alcohol excess immediately before the acute attack. Biliary acute pancreatitis was assumed when gallstones were found on subsequent ultrasound examination, CT, or endoscopic retrograde cholangiopancreatography. Other causes of acute pancreatitis were endoscopic procedures (endoscopic retrograde cholangiopancreatography), trauma, viral infection, Salmonella infection, and drugs.

On the basis of these definitions, the causes of acute pancreatitis were found to be biliary in $114(40 \%)$ patients, alcohol abuse in $83(29 \%)$, and unknown in $66(23 \%)$. In the remaining 21 (7\%) patients, other causes were discovered.

Abbreviation used in this paper: $\mathrm{CT}$, computed tomography. 
Table 1 Causes of the disease and serum amylase and lipase levels (divided into group $A(\leqslant 3 n)$ and group $B(>3 n)$ ) in 284 patients with a first attack of acute pancreatitis obtained on admission to hospital

\begin{tabular}{|c|c|c|c|c|c|c|c|c|c|c|}
\hline \multirow{3}{*}{$\begin{array}{l}\text { Cause of the } \\
\text { disease }\end{array}$} & & & \multicolumn{4}{|c|}{ Serum amylase levels } & \multicolumn{4}{|c|}{ Serum lipase levels } \\
\hline & \multicolumn{2}{|c|}{ Patients } & \multicolumn{2}{|c|}{$\begin{array}{l}\text { Group } A: \leqslant 3 n \\
(n=88)\end{array}$} & \multicolumn{2}{|c|}{$\begin{array}{l}\text { Group B: }>3 n \\
(n=196)\end{array}$} & \multicolumn{2}{|c|}{$\begin{array}{l}\text { Group } A: \leqslant 3 n \\
(n=51)\end{array}$} & \multicolumn{2}{|c|}{$\begin{array}{l}\text { Group B: }>3 n \\
(n=233)\end{array}$} \\
\hline & $n$ & $\%$ & $n$ & $\%$ & $n$ & $\%$ & $n$ & $\%$ & $n$ & $\%$ \\
\hline Biliary & 114 & 40.1 & 25 & 21.9 & 89 & 78.1 & 18 & 15.8 & 96 & 84.2 \\
\hline Alcoholism & 83 & 29.2 & 34 & 41.0 & 49 & 59.0 & 13 & 15.7 & 70 & 84.3 \\
\hline Other & 21 & 7.4 & 12 & 57.1 & 9 & 42.9 & 8 & 38.1 & 13 & 61.9 \\
\hline Unknown & 66 & 23.2 & 17 & 25.8 & 49 & $74.2^{\star}$ & 12 & 18.2 & 54 & $81.8 \rrbracket$ \\
\hline Biliary & 114 & 40.1 & 25 & 21.9 & 89 & 78.1 & 18 & 15.8 & 96 & 84.2 \\
\hline Non-biliary & 170 & 59.9 & 63 & 37.1 & 107 & $62.9 \dagger$ & 33 & 19.4 & 137 & $80.6 \uparrow$ \\
\hline Alcoholics & 83 & 29.2 & 34 & 41.0 & 49 & 59.0 & 13 & 15.7 & 70 & 84.3 \\
\hline Non-alcoholics & 201 & 70.8 & 54 & 26.9 & 147 & $73.1 \ddagger$ & 38 & 18.9 & 163 & $81.1^{\star \star}$ \\
\hline
\end{tabular}

$\chi^{2}$ test of independence: ${ }^{\star} \mathrm{p}=0.001 ; \mathrm{tp}=0.007 ; \neq \mathrm{p}=0.019 ; \mathrm{g}=0.09$, not significant; $\uparrow \mathrm{p}=0.44$, not significant; ${ }^{\star \star} \mathrm{p}=0.52$, not significant.

Patients $(\mathrm{n}=284)$ were divided into two groups according to their serum enzyme levels on admission: group $\mathrm{A}$, three times or less than the upper limit of normal $(\leqslant 3 n)$; group $B$, more than three times the upper limit of normal $(>3 n)$. In group A, amylase and lipase levels of $\leqslant 3 \mathrm{n}$ were found in $88(31 \%)$ and 51 $(18 \%)$ patients respectively. In group B, amylase and lipase levels of $>3 n$ were found in $196(69 \%)$ and $233(82 \%)$ respectively.

To evaluate the severity of the disease, the following prognostic criteria were used: increased serum creatinine levels of $\geqslant 1.1 \mathrm{mg} / \mathrm{dl}$ within the first 48 hours of admission and after rehydration ( $\mathrm{n}=80,28 \%)$, indication for dialysis $(n=10,4 \%)$, artificial ventilation during hospital stay $(\mathrm{n}=19,7 \%)$. For further evaluation, the development of a pancreatic pseudocyst $(\mathrm{n}=34,12 \%)$ and the indication for surgical treatment $(n=25,9 \%)$ were used. Indication for surgical treatment was infected necrosis. Necrosectomy was performed in all 25 surgical patients; in six of them, a left sided resection was necessary. Finally the death rate $(\mathrm{n}=11,4 \%)$ was also used. The cause of death in all 11 patients was acute pancreatitis. Six of them had undergone surgical treatment. Three died in the first week, two in the second and six after the second week.

For comparison of the results of both groups the $\chi^{2}$ test of independence and Fisher's exact test were used.

\section{Results}

Table 1 shows the correlation of the cause of the disease with serum amylase/lipase levels. There were significant differences with regard to amylase, but not lipase increase.
Significantly more patients with biliary induced acute pancreatitis had serum amylase levels $>3 n$ on admission $(p=0.007)$. Furthermore, alcoholics had significantly less elevated amylase levels $(\leqslant 3 n)$ than non-alcoholics $(p=$ 0.019 ). Again, these differences were only true for amylase, and not for lipase.

The incidence of all clinical parameters was the same for patients with serum amylase and lipase levels $\leqslant 3 n$ and $>3 n$ respectively (table 2 ). There were also no differences with respect to enzyme increase and early and late death rate.

When surgical procedures were divided into necrosectomy and necrosectomy plus left sided resection, there were no significant differences among surgical procedures and amylase and lipase increase (data not shown).

\section{Discussion}

There are no studies correlating serum enzyme level elevation on admission with the course of acute pancreatitis. There are only two surgical and two non-surgical studies comparing initial enzyme levels with the degree of destruction of the pancreas. Abruzzo et $a l^{12}$ found hypoamylasaemia in patients with acute pancreatitis and severe destruction of the pancreas. Adams et $a l^{13}$ found an inverse relation between amylase and severe morphological changes. Whereas patients with a large amylase increase showed minimal or moderate pancreatitis, those with a smaller amylase increase were found to have severe pancreatitis at surgery. Two studies correlating serum enzyme levels on admission with the results of contrast enhanced CT came to different conclusions. Whereas Winslet et $a l^{14}$ showed that patients with low enzyme levels

Table 2 Parameters of severity of the disease and serum amylase and lipase levels (divided into group $A$ ( $\leqslant 3 n$ ) and group $B(>3 n))$ in 284 patients with a first attack of acute pancreatitis obtained on admission to hospital

\begin{tabular}{|c|c|c|c|c|c|c|c|c|c|c|}
\hline \multirow[b]{3}{*}{ Parameters } & \multicolumn{4}{|c|}{ Serum amylase levels } & \multirow[b]{3}{*}{$p$ Value ${ }^{\star}$} & \multicolumn{4}{|c|}{ Serum lipase levels } & \multirow[b]{3}{*}{$p$ Value * } \\
\hline & \multicolumn{2}{|c|}{$\begin{array}{l}\text { Group } A: \leqslant 3 n \\
(n=88)\end{array}$} & \multicolumn{2}{|c|}{$\begin{array}{l}\text { Group B: }>3 n \\
(n=196)\end{array}$} & & \multicolumn{2}{|c|}{$\begin{array}{l}\text { Group } A: \leqslant 3 n \\
(n=51)\end{array}$} & \multicolumn{2}{|c|}{$\begin{array}{l}\text { Group B: }>3 n \\
(n=233)\end{array}$} & \\
\hline & $n$ & $\%$ & $n$ & $\%$ & & $n$ & $\%$ & $n$ & $\%$ & \\
\hline Renal impairment & 21 & 23.7 & 59 & 30.1 & $0.32, \mathrm{NS}$ & 15 & 29.4 & 65 & 27.9 & $0.86, \mathrm{NS}$ \\
\hline Dialysis & 2 & 2.3 & 3 & 1.5 & $0.65, \mathrm{NS}$ & 1 & 1.9 & 4 & 1.7 & $1.00, \mathrm{NS}$ \\
\hline Artificial ventilation & 5 & 5.7 & 14 & 7.1 & $0.80, \mathrm{NS}$ & 3 & 5.9 & 16 & 6.9 & $1.00, \mathrm{NS}$ \\
\hline Pseudocysts & 10 & 11.4 & 24 & 12.2 & $1.00, \mathrm{NS}$ & 4 & 7.8 & 30 & 12.9 & $0.47, \mathrm{NS}$ \\
\hline Surgical treatment & 11 & 12.5 & 14 & 7.1 & $0.17, \mathrm{NS}$ & 6 & 11.8 & 19 & 8.2 & $0.42, \mathrm{NS}$ \\
\hline Mortality & 4 & 4.5 & 7 & 3.6 & $0.74, \mathrm{NS}$ & 3 & 5.9 & 8 & 3.4 & 0.42 , NS \\
\hline
\end{tabular}

^Fisher's exact test. 
$(\leqslant 3 n)$ more frequently had pancreatic necrosis, we failed to confirm this. ${ }^{15}$ Further studies on the relation between serum enzymes on admission and CT scores would be of interest. However, it should be kept in mind that pancreatic necrosis and organ failure do not correlate well and may occur independently in acute pancreatitis. ${ }^{16}{ }^{17}$

Our study with a substantial number of patients shows that severe acute pancreatitis as assessed by moderate and severe organ failure, systemic and local complications, and mortality is independent of the initial enzyme levels, in this case $\leqslant />3 n$, the borderline frequently used in controlled studies on the treatment of severe acute pancreatitis. There is no other study with which we can directly compare ours on the relation between serum enzyme levels on admission and the severity of the disease.

In conclusion, pancreatologists should not rely in future studies on elevated enzyme levels of $>3 \mathrm{n}$ for diagnostic and thus inclusion criteria. Patients with $\leqslant 3 n$ enzyme levels on admission represent a substantial group that treatment studies have so far overlooked. This is especially true for patients with alcohol induced acute pancreatitis, a large aetiological subgroup, whose amylase levels on admission are lower than in other aetiological subgroups, as we and others have already shown. ${ }^{18-23}$ For non-pancreatologists the conclusion from this study is that the prognostic severity of acute pancreatitis is independent of serum enzyme level elevation on admission. Patients with only a small increase in amylase/lipase levels can also have or develop severe acute pancreatitis. Therefore the clinician who makes the initial diagnosis must evaluate the severity of the disease independently of the enzyme level elevation, as the complication rate, indication for surgical treatment, and death rate are not related to the initial enzyme increase.

1 MRC Multicentre Trial of Glucagon and Aprotinin. Death from acute pancreatitis. Lancet 1977;2:632-5.

2 Goebell H, Ammann R, Herfarth C, et al. A double-blind trial of synthetic salmon calcitonin in the treatment of
acute pancreatitis. Scand $\mathcal{F}$ Gastroenterol 1979;14:881-9.
3 Paul F, Ohnhaus EE, Hesch RD, et al. Einflu $\beta$ von Salm-Calcitonin auf den Verlauf der akuten Pankreatitis. Ergebnisse einer prospektiven Doppelblindstudie. Dtsch Med Wochenschr 1979;104:615-22.

4 Medical Research Council Multicentre Trial. Morbidity of acute pancreatitis: the effect of aprotinin and glucagon. Gut 1980;21:334-9.

5 Usadel KH, Überla KK, Leuschner U. Treatment of acute pancreatitis with somatostatin: results of the multicenter double-blind trial (APTS-study) [abstract]. Dig Dis Sci 1985;30:992.

6 Freise J, Melzer P, Schmidt FW, et al. Gabexat mesilat in der hannoverschen multizentrischen Doppelblindstudie mit 50 Patienten. Z Gastroenterol 1986;24:200-11.

7 Choi TK, Mok F, Zhan WH, et al. Somatostatin in the treatment of acute pancreatitis: a prospective randomised controlled trial. Gut 1989;30:223-7.

8 Büchler M, Malfertheiner P, Uhl W, et al. Gabexate mesilate in human acute pancreatitis. Gastroenterology 1993;104: 1165-70.

9 Kingsnorth AN, Galloway SW, Formela LJ. Randomized, double-blind phase II trial of Lexipafant, a plateletactivating factor antagonist, in human acute pancreatitis. Br f Surg 1995;82:1414-20.

10 McKay CJ, Curran F, Sharples C, et al. Prospective placebo-controlled randomized trial of lexipafant in predicted severe acute pancreatitis. Br f Surg 1997;84: 1239-43.

11 Sarner M, Cotton PB. Classification of pancreatitis. Gut 1984;25:756-9.

12 Abruzzo JL, Homa M, Houck JC, et al. Significance of the serum amylase determination. Ann Surg 1958;147:921-30. 13 Adams JT, Libertino JA, Schwartz SI. Significance of an elevated serum amylase. Surgery 1968;63:877-84.

14 Winslet M, Hall C, London NJM, et al. Relation of diagnostic serum amylase levels to aetiology and severity of acute pancreatitis. Gut 1992;33:982-6.

15 Lankisch PG, Petersen M, Gottesleben F. High, not low, amylase and lipase levels indicate severe acute pancreatitis. $Z$ Gastroenterol 1994;32:213-15.

16 Tenner S, Sica G, Hughes M, et al. Relationship of necrosis to organ failure in severe acute pancreatitis. Gastroenterology 1997;113:899-903.

17 Lankisch PG, Pflichthofer D, Assmus C. The development of pancreatic necrosis and multi-system organ failure is not a parallel event in acute pancreatitis (AP) [abstract]. Gastroenterology 1997;112:A455.

18 Paloyan D, Simonowitz D. Diagnostic considerations in acute alcoholic and gallstone pancreatitis. Am F Surg 1976; 132:329-31.

19 Croton RS, Warren RA, Stott A, et al. Ionized calcium in acute pancreatitis and its relationships with total calcium and serum lipase. Br F Surg 1981;68:241-4.

20 Nordestgaard AG, Wilson SE, Williams RA. Correlation of serum amylase levels with pancreatic pathology and pancreatitis etiology. Pancreas 1988;3:159-62.

21 Hiatt JR, Calabria RP, Passaro E, Jr, et al. The amylase profile: a discriminant in biliary and pancreatic disease. $\mathrm{Am}$ F Surg 1987;154:490-2.

22 Tenner SM, Steinberg W. The admission serum lipase: amylase ratio differentiates alcoholic from nonalcoholic acute pancreatitis. Am $\mathcal{F}$ Gastroenterol 1992;87:1755-8.

23 Lankisch PG, Petersen M. Lipase/amylase ratio: not helpful in the early etiological differentiation of acute pancreatitis. Z Gastroenterol 1994;32:8-11. 